\title{
PENINGKATAN PEMAHAMAN KONSEP PELUANG MELALUI MODEL DISCOVERY LEARNING
}

\author{
Reka Damayana ${ }^{1}$, Andinasari ${ }^{2}$, Lusiana $^{3}$ \\ 1,2,3Fakultas Keguruan dan Ilmu Pendidikan, Universitas PGRI Palembang \\ 1,2,3 Jalan A. Yani. Lrg. GotongRoyong 9/10 Ulu Palembang \\ Email: rekadamayana4@gmail.com¹, andinasari_yulianto@yahoo.com², \\ luu_sii_ana@gmail.com ${ }^{3}$
}

\begin{abstract}
Abstrak:
Penelitian ini bertujuan untuk mengetahui apakah terdapat peningkatan kemampuan pemahaman konsep matematis siswa setelah diberikan perlakuan, yaitu pembelajaran dengan model discovery learning. Jenis penelitian ini adalah penelitian eksperimen dengan desain pembelajaran the one-group pretest-postest design. Variabel yang diukur dalam penelitian ini yaitu peningkatan kemampuan pemahaman konsep matematis siswa dan variabel perlakuan yaitu model discovery learning. Sampel dalam penelitian ini adalah kelas VIII.11. Teknik pengumpulan data menggunakan tes. Teknik analisis yang digunakan adalah uji Gain ternormalisasi ( $N$-Gain). Berdasarkan hasil analisis uji $\mathrm{N}$-Gain data tes awal (pretest) dan tes akhir (postest) diperoleh indeks ga in 0,74 dengan kategori tinggi dengan nilai rata-rata pretest yaitu 38,33 dan nilai rata-rata posttest yaitu 84,69. Oleh karena itu, terdapat perbedaan kemampuan pemahaman konsep matematis siswa setelah diterapkan model pembelajaran discovery learning.
\end{abstract}

\begin{abstract}
:
The purpose of this study is to find out whether there is an increase in the ability to understand students' mathematical concepts through discovery learning models. The implementation of mathematics learning is still teacher center, this causes the ability to understand students' mathematical concepts is not maximal. The variables measured in this study are increasing the ability to understand students' mathematical concepts and treatment variables, namely discovery learning model. the subject in this study was class VIII.11 and used the quasy method experimental with learning design the one-group pretest-postest design. Data collection techniques using tests. The analysis technique used is the N-Gain Test. Based on the results of the analysis of the initial test N-Gain data (pretest) and the final test (posttest) obtained index gain 0.74 which has a high interpretation with a pretest average value of 38.33 and the posttest average value is 84.69 . Then it can be concluded that there is an increase in the ability to understand the mathematical concepts of students after the discovery learning learning model is applied in high categorization.
\end{abstract}

Kata kunci:

Model Discovery Learning, Pemahaman Konsep Matematis

How to Cite: Damayana, R., Andinasari, \& Lusiana. (2019). Peningkatan Pemahaman Konsep Peluang Melalui Model Discovery Learning. Lentera Pendidikan : Jurnal Ilmu Tarbiyah dan Keguruan, 22(2), 223-232. 


\section{PENDAHULUAN}

Matematika merupakan mata pelajaran yang selalu diajarkan pada semua tingkatan pendidikan, baik tingkat dasar, tingkat menengah, hingga tingkat perguruan tinggi. Dapat dikatakan bahwa matematika menjadi salah satu mata pelajaran yang sangat penting dan memiliki fungsi bagi perkembangan siswa di sekolah. Hamzah (2014: 68) menjelaskan fungsi matematika di sekolah adalah sebagai wahana latihan bagi siswa agar mampu berfikir logis, rasional, kritis, cermat, jujur, efisien, dan efektif, yang dibentuk melalui setiap proses yang terjadi dalam pembelajaran matematika. Berdasarkan tujuan pembelajaran matematika di sekolah, kemampuan pemahaman konsep menjadi sesuatu yang sangat dibutuhkan dalam pembelajaran matematika. Adapun kemampuan pemahaman konsep peserta didik berbeda-beda ditinjau dari kemampuannya dalam menyelesaikan masalah matematika.

Namun, pada kenyataannya banyak siswa yang mengaku kesulitan dalam belajar matematika termasuk dalam hal memahami konsep matematika yang menyebabkan rendahnya nilai rata-rata hasil belajar siswa (Mawaddah \& Maryanti, 2016: 77). Salah satu yang menjadi faktornya, yaitu guru aktif memberi informasi dan siswa pasif menerima informasi sehingga siswa tidak terlibat secara aktif dan tidak mendapatkan kesempatan memunculkan ide-ide kreatif dalam menemukan alternatif dan memecahkan masalah (Kurniadi \& Purwaningrum, 2018: 9). Sejalan dengan pernyataan Andinasari, Zulkardi, Somakim, \& Wasiran (2018: 2) bahwa pembelajaran yang berpusat pada guru, mengakibatkan kurangnya partisipasi siswa dalam belajar. Oleh karena itu, pembelajaran seharusnya melibatkan siswa secara aktif agar pembelajaran tidak fokus pada menghafal konsep, agar kemampuan pemahaman konsep matematis lebih maksimal, dan siswa mampu menyelesaikan permasalahan matematis yang diberikan. Hal ini sangat berdampak pada hasil belajar siswa, karena kurang maksimalnya kemampuan pemahaman konsep matematis siswa, sehingga terkadang siswa kesulitan menyelesaikan masalah peluang.

Kegiatan pembelajaran yang berpusat pada guru yang dilakukan secara terus menerus mengakibatkan siswa cenderung pasif dan kurang kreatif dalam mengutarakan ide-ide dan siswa seringkali mengalami kesulitan dalam mengerjakan soal-soal yang diberikan guru. Sebagai contoh, pada materi peluang. Menurut Aisyah, Sumintono, \& Ismail (2014) masalah yang dialami siswa pada materi peluang, yaitu siswa mengalami miskomunikasi akibat kekeliruan dalam membandingkan dua hal tertentu, siswa mengalami kesulitan menyelesaikan masalah peluang karena kurang menguasai dengan baik konsep dasar dari peluang, siswa cenderung hanya menghafalkan rumus, kurang memahami istilah yang digunakan dalam materi peluang, serta kurang memahami konsep peluang yang melibatkan operasi matematika tertentu, sehingga mereka kurang dapat menyelesaikan soal yang berkaitan dengan materi peluang. Hal ini menunjukkan bahwa tingkat kemampuan pemahaman konsep matematis siswa masih kurang maksimal dan perlu ditingkatkan.

Berdasarkan masalah tersebut, meningkatkan kemampuan pemahaman konsep matematis siswa sangatlah penting. Dalam proses pembelajaran diperlukan cara yang 
mampu mendorong siswa untuk memahami masalah, meningkatkan kemampuan pemahaman konsep matematis siswa dalam menyusun rencana penyelesaian dan melibatkan siswa secara aktif dalam menemukan sendiri penyelesaian masalah, serta menjadikan pembelajaran yang mengarahkan siswa untuk belajar secara aktif dan terlibat dalam proses pembelajaran. Sejalan dengan pernyataan Lusiana (2018: 368) dalam pembelajaran matematika, siswa harus diarahkan dan dibimbing agar mampu menggunakan berbagai situasi dan kesempatan untuk menemukan pengetahuan matematika dengan cara mereka sendiri.

Pembelajaran matematika perlu dirancang sedemikian rupa sehingga menjadi salah satu alternatif yang tepat untuk dijadikan solusi. Dalam proses pembelajaran diperlukan cara yang bisa mendorong siswa untuk memahami masalah, meningkatkan kemampuan pemahaman konsep matematis siswa dalam menyusun rencana penyelesaian dan melibatkan siswa secara aktif dalam menemukan sendiri penyelesaian masalah, serta mendorong pembelajaran yang berpusat pada siswa dan guru hanya sebagai fasilitator. Dalam menumbuhkan kemampuan pemahaman konsep matematis siswa, yaitu dengan mendorong dan membimbing siswa untuk melakukan setiap langkah pembelajaran secara langsung, agara mereka mengalami dan menemukan sendiri unsur-unsur yang akan membangun pemahaman konsep siswa. Oleh karena itu, dalam penelitian ini menggunakan model pembelajaran discovery learning untuk mengatasi permasalahan yang ada.

Berdasarkan pernyataan Mawaddah \& Maryanti (2016: 77-79) dapat dikatakan model pembelajaran penemuan (discovery learning) merupakan salah satu model pembelajaran yang menempatkan guru sebagai fasilitator, siswa menemukan sendiri pengetahuan yang belum mereka ketahui dengan dibimbing oleh pertanyaanpertanyaan dari guru, maupun LKPD, sehingga dapat disimpulkan bahwa pemahaman konsep matematis siswa dapat dilihat setelah siswa memenuhi indikator kemampuan pemahaman konsep dengan menyatakan ulang konsep tersebut, mengklasifikasikan objek menurut sifat tertentu, memberikan contoh dan bukan contoh konsep, menyajikan konsep dalam representasi matematis, menggunakan prosedur tertentu dan mengaplikasikan konsepnya pada pemecahan masalah dalam proses pembelajaran matematika.

Kodirun, Busnawir, \& Viktor (2016: 95) berpendapat bahwa model pembelajaran penemuan (discovery learning) merupakan cara mengembangkan kegiatan belajar siswa aktif yang menggunakan proses mental untuk menemukan sesuatu konsep atau prinsip. Adapun indikator dari pemahaman konsep matematis menurut Zaini (2018: 115) yaitu: menyatakan ulang setiap konsep; mengklarifikasikan objek-objek menurut sifat-sifat tertentu; memberikan contoh dan non-contoh dari konsep; menyajikan konsep dalam berbagai bentuk representasi matematis; mengembangkan syarat perlu atau syarat cukup suatu konsep; menggunakan, memanfaatkan, dan memilih prosedur atau operasi tertentu; mengaplikasikan konsep atau algoritma pemecahan masalah.

Dalam penelitian ini, pembelajaran discovery learning diartikan sebagai pembelajaran yang efektif untuk diterapkan kepada peserta didik, karena dalam 
pelaksanaannya peserta didik didorong dan dibimbing untuk menemukan sendiri pengetahuan baik berupa konsep, prinsip, dan lain-lain. Pembelajaran ini bertujuan meningkatkan kemampuan pemahaman konsep matematis siswa yang mengacu pada beberapa indikator, yaitu siswa mampu menyatakan ulang konsep dengan kemampuan sendiri, siswa mampu mengindentifikasi objek-objek menurut sifat-sifat, siswa mampu memberikan contoh dan non contoh dari konsep, siswa mampu menyajikan konsep dalam berbagai bentuk representasi matematika, mengembangkan syarat perlu atau syarat cukup suatu konsep, menggunakan, memanfaatkan dan memilih prosedur atau operasi tertentu, dan siswa mampu mengaplikasikan konsep atau algoritma dalam pemecahan masalah, sehingga menjadikan siswa lebih aktif saat proses pembelajaran berlangsung.

\section{METODE PENELITIAN}

Jenis penelitian yang digunakan adalah penelitian eksperimen dengan desain pembelajaran the one-group pretest-postest design, melalui penerapan model pembelajaran discovery learning. Populasi penelitian ini adalah seluruh siswa kelas VIII SMP Negeri 1 OKU pada tahun ajaran 2018/2019, terdiri dari 11 kelas yang berjumlah 352 siswa dan sampel dalam penelitian ini adalah siswa kelas VIII.11 yang berjumlah 32 orang yang terdiri dari 15 orang laki-laki dan 17 orang perempuan. Desain penelitian ini dapat dilihat pada gambar 1 dibawah ini.

\begin{tabular}{|lll|}
\hline $\mathbf{O}_{1}$ & $\mathbf{X}$ & $\mathbf{O}_{2}$ \\
\hline
\end{tabular}

Gambar 1. The One-Group Pretest-Postest Design

Keterangan:

$\mathrm{X}=$ Perlakuan/treatment yang diberikan

$\mathrm{O}_{1}=$ Pretest diberikan sebelum penerapan model pembelajaran penemuan (discovery learning)

$\mathrm{O}_{2}=$ Postest diberikan setelah penerapan model pembelajaran penemuan (discovery learning)

Siswa diberikan pretest kemudian diberikan perlakuan pada 3 pertemuan sesuai dengan materi peluang yang akan disampaikan yaitu peluang empirik, ruang sampel dan titik sampel suatu peluang, serta peluang teoritik selanjutnya diberikan posttest di pertemuan terakhir. Instrumen tes pemahaman konsep matematis siswa yang sudah dibuat kemudian diuji validitas isi dan reliabilitasnya. Untuk menghitung validasi soal digunakan rumus Pearson Product Moment, sebagai berikut.

$$
r_{x y}=\frac{n(\Sigma X Y)-(\Sigma X)(\Sigma Y)}{\sqrt{\left\{n \Sigma X^{2}-\left((\Sigma X)^{2}\right)\right\}\left\{n \Sigma Y^{2}-\left((\Sigma Y)^{2}\right)\right\}}}
$$

Namun, untuk menentukan reliabilitas digunakan rumus Alpha Cronbach, yang merupakan suatu prosedur pencarian nilai reliabilitas dengan tidak mensyaratkan 
pembelahan item ke dalam dua kelompok, sehingga diterapkan pada item tidak genap, dengan rumus (Arikunto, 2014: 122):

$$
r_{11}=\left(\frac{n}{n-1}\right)\left(1-\frac{\sum \sigma_{i}}{\sigma_{t}}\right)
$$

Berdasarkan hasil uji coba instrumen penilaian, instrumen yang digunakan telah memenuhi validitas isi dan dinyatakan valid. Berdasarkan hasil analisis data tes uji coba, koefisien reliabilitas instrumen tes yang diperoleh sebesar 0,60 sehingga instrumen tes dikatakan reliabel. Dengan demikian, dapat disimpulkan bahwa instrumen tes dapat digunakan untuk mengukur kemampuan pemahaman konsep matematis siswa.

Sebelum melakukan pengolahan data, langkah yang ditempuh adalah melakukan pengumpulan data melalui tes. Tes tersebut berbentuk essai atau uraian yang memenuhi indikator kemampuan pemahaman konsep matematis siswa. Kemudian data dianalisis menggunakan gain ternormalisasi atau uji $\mathrm{N}$-Gain dalam pengambilan kesimpulan.

Menurut Lestari (2015: 234-235) data N-Gain atau gain ternormalisasi merupakan data yang diperoleh dengan membandingkan selisih skor postest dan pretest dengan selisih Skor Maksimum Ideal (SMI) dan pretest, atau secara matematis pada rumus berikut.

$$
N-\text { Gain }=\frac{\text { Skor postest }- \text { Skor pretest }}{\text { SMI-Skor pretest }}
$$

\section{HASIL PENELITIAN DAN PEMBAHASAN} berikut.

Data deskriptif pemahaman konsep matematis siswa disajikan pada tabel

Tabel 1. Hasil Tes Kemampuan Pemahaman Konsep Matematis Siswa

\begin{tabular}{cccc}
\hline Statistik & $\mathbf{N}$ & $\overline{\boldsymbol{x}}$ & $\mathbf{S}$ \\
\hline Pretest & 32 & 38,33 & 17,12 \\
\hline Postest & 32 & 84,69 & 7,08
\end{tabular}

Data hasil penelitian menunjukan bahwa nilai rata-rata hasil tes awal (pretest) kemampuan pemahaman konsep matematis siswa sebelum diberi perlakuan lebih kecil dibandingkan dengan nilai rata-rata hasil tes akhir (postest). Adapun hasil analisis peningkatan kemampuan pemahaman konsep matematis siswa per indikator dapat dilihat pada tabel dibawah ini.

Tabel 2. Hasil Rata-Rata Tes Akhir Siswa Perindikator

\begin{tabular}{ccccccc}
\hline No. & $\begin{array}{c}\text { Indikator } \\
\text { Pemahaman Konsep }\end{array}$ & $\begin{array}{c}\text { Skor } \\
\text { Maks }\end{array}$ & $\begin{array}{c}\text { Skor } \\
\text { Pretes }\end{array}$ & $\begin{array}{r}\text { Skor } \\
\text { Postes }\end{array}$ & N-Gain & Interpretasi \\
\hline 1. $\begin{array}{l}\text { Siswa mampu menjelaskan } \\
\text { pengertian atau definisi } \\
\text { dengan menyimpulkan } \\
\text { dengan bahasa sendiri }\end{array}$ & 96 & 56 & 90 & 0,61 & Sedang \\
\hline
\end{tabular}




\begin{tabular}{|c|c|c|c|c|c|c|}
\hline 2 & $\begin{array}{l}\text { Siswa mampu menetapkan } \\
\text { objek-objek berdasarkan } \\
\text { sifat tertentu }\end{array}$ & 96 & 25 & 94 & 0,97 & Tinggi \\
\hline 3 & $\begin{array}{l}\text { Siswa mampu membedakan } \\
\text { contoh dari suatu konsep } \\
\text { dan yang bukan contoh dari } \\
\text { suatu konsep }\end{array}$ & 96 & 72 & 90 & 0,75 & Tinggi \\
\hline 4 & $\begin{array}{l}\text { Menunjukan konsep dalam } \\
\text { berbagai bentuk } \\
\text { matematika }\end{array}$ & 288 & 94 & 218 & 0,64 & Sedang \\
\hline 5 & $\begin{array}{l}\text { Mampu menggunakan } \\
\text { syarat perlu atau syarat } \\
\text { cukup suatu konsep }\end{array}$ & 96 & 51 & 93 & 0,93 & Tinggi \\
\hline 6 & $\begin{array}{l}\text { Menggunakan, } \\
\text { memanfaatkan dan memilih } \\
\text { prosedur atau operasi } \\
\text { tertentu }\end{array}$ & 192 & 45 & 157 & 0,76 & Tinggi \\
\hline 7 & $\begin{array}{l}\text { Siswa mampu } \\
\text { menggunakan konsep atau } \\
\text { algoritma dalam pemecahan }\end{array}$ & 96 & 25 & 68 & 0,61 & Sedang \\
\hline
\end{tabular}

Dari tabel 2 diketahui bahwa indikator siswa mampu menjelaskan pengertian atau definisi dengan menyimpulkan dengan bahasa sendiri, indikator siswa mampu menetapkan objek-objek berdasarkan sifat tertentu, indikator siswa mampu membedakan contoh dari suatu konsep dan yang bukan contoh dari suatu konsep, indikator menunjukan konsep dalam berbagai bentuk matematika, indikator mampu menggunakan syarat perlu atau syarat cukup suatu konsep, indikator menggunakan, memanfaatkan dan memilih prosedur atau operasi tertentu, dan indikator siswa mampu menggunakan konsep atau algoritma dalam pemecahan masalah mengalami peningkatan dengan kategori tinggi. Sedangkan peningkatan dalam kategori sedang terjadi pada indikator siswa mampu menyatakan ulang konsep dengan kemampuan sendiri, menyajikan konsep dalam berbagai bentuk representasi matematika, dan siswa mampu menggunakan konsep atau algoritma dalam pemecahan masalah.

Tabel 3. Hasil Analisis N-Gain Tes Awal (Pretest) dan Tes Akhir (Postest)

\begin{tabular}{cccc}
\hline $\begin{array}{c}\text { Rata-Rata } \\
\text { Pretest }\end{array}$ & $\begin{array}{c}\text { Rata-Rata } \\
\text { Posttest }\end{array}$ & $\begin{array}{c}\text { Indeks } \\
\text { Gain }\end{array}$ & Kategori \\
\hline 38,33 & 84,69 & 0,74 & Tinggi \\
\hline
\end{tabular}

Dari tabel 3, diperoleh informasi nilai rata-rata tes awal siswa adalah 38,33 sedangkan nilai rata-rata tes akhir siswa adalah 84,69 sehingga diperoleh indeks gain sebesar 0,74. Setelah diinterpretasikan ke dalam klasifikasi Hake maka indeks gain termasuk ke dalam katagori tinggi. Oleh karena itu, dapat disimpulkan bahwa peningkatan kemampuan pemahaman konsep matematis siswa setelah diterapkan 
model pembelajaran discovery learning di SMP Negeri 1 OKU berada pada kategori tinggi.

Salah satu contoh pada indikator ketiga yaitu siswa mampu membedakan contoh dan non contoh dari konsep mengalami peningkatan yang tinggi dengan indeks gain 0,79 dengan interpretasi tinggi. Hal ini memberikan informasi bahwa pada saat tes awal (pretest) siswa belum sepenuhnya dapat memberikan yang mana contoh dan yang bukan contoh dari konsep yang ada. Seperti pada Gambar 2.

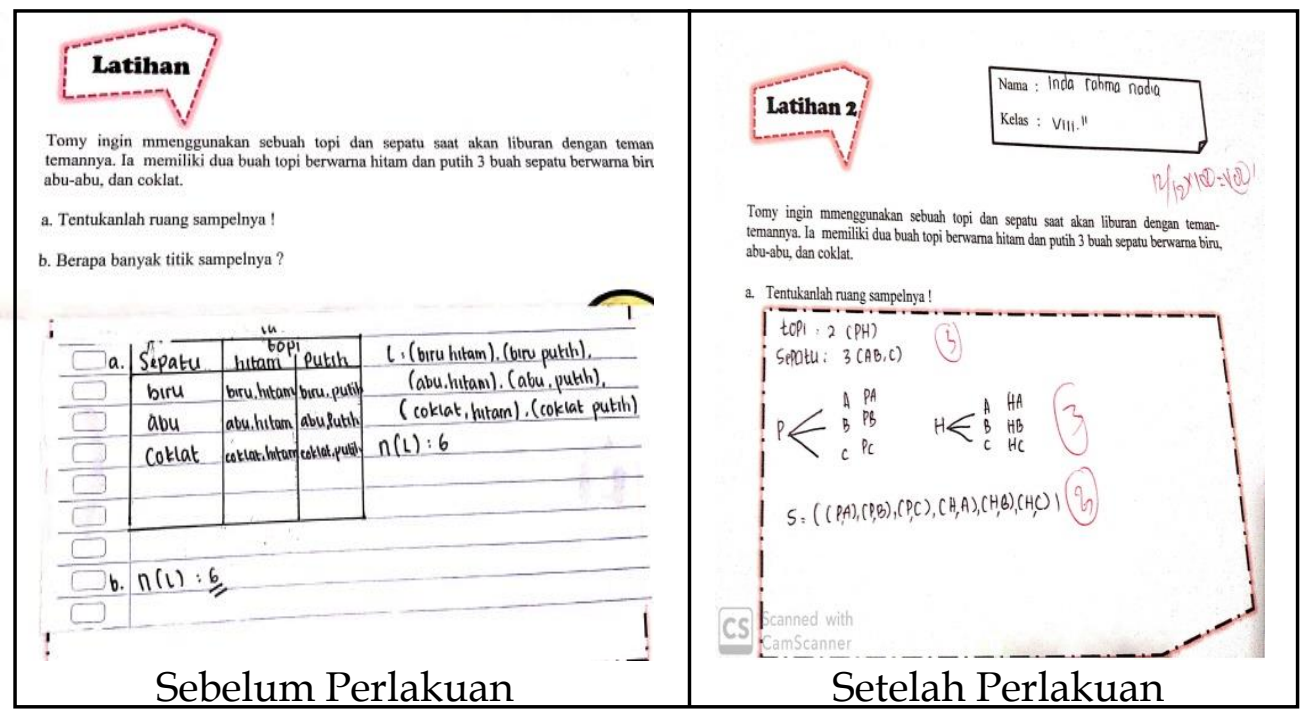

Gambar 2. Jawaban Soal Menyajikan Konsep dalam Berbagai Representasi Matematis

Berdasarkan gambar 2 diperoleh informasi bahwa sebelum perlakuan model pembelajaran discovery learning siswa memang sudah mempunyai kemampuan dalam menentukan ruang sampel, namun bentuk representasinya masih belum sederhana, karena belum menggunakan notasi dalam bentuk matematis. Berbeda halnya setelah diberikan perlakuan, siswa sudah mampu menyajikan data dalam bentuk yang lebih sederhana (bahasa matematis) dengan memisalkan contoh topi hitam dan topi putih dengan huruf kapital $\mathrm{H}$ dan $\mathrm{P}$, terlihat dari jawaban siswa setelah diterapkannya model pembelajaran discovery learning.

Pada saat pelaksanaan penelitian, yaitu pada pembelajaran matematika menggunakan model pembelajaran discovery learning yang dilakukan di SMP Negeri 1 OKU, didapatkan temuan pada saat proses pembelajaran, yakni pada tahapan stimulation siswa diberikan rangsangan berupa media yang bisa menarik minat siswa untuk mempelajari suatu materi yaitu LKPD dan logam. Sejalan dengan pendapat Suprihatiningrum (2017: 248) bahwa dengan tahapan ini dapat memotivasi siswa untuk terlibat dalam kegiatan pembelajaran. Oleh karena itu, peneliti dapat memberikan media atau apapun yang berkaitan dengan materi yang akan dipelajari.

Selanjutnya, pada tahap pengumpulan data (data collection) dan pengolahan data (data processing), siswa terlibat secara aktif misalnya dalam pengerjaan LKPD. Dengan 
memanfaatkan media logam, siswa diinstruksikan untuk melakukan percobaan misalnya melakukan pelemparan logam minimal 10 kali, dan mereka mencatat setiap hasil percobaan pada tabel yang tersedia, kemudian dibimbing mengolah data yang telah terkumpul di dalam tabel.

Dalam kegiatan ini siswa sangat antusias, karena biasanya guru yang mendemonstrasikan penggunaan media, tapi dalam pembelajaran discovery learning siswa yang diharuskan terlibat secara aktif, dan mereka yang menemukan serta mengalami sendiri setiap proses untuk memperoleh pengetahuan. Suprihatiningrum (2013) menambahkan bahwa dalam pembelajaran discovery learning guru menekankan keterlibatan siswa secara aktif, yaitu dengan guru memberikan pertanyaan dan membolehkan siswa untuk menemukan ide dan teori mereka sendiri, sehingga proses pembelajaran berlangsung dua arah, dan terjadi aksi timbal balik yang baik antara pendidik dan siswa.

Berdasarkan penjelasan sebelumnya, model pembelajaran discovery learning dapat menjadi salah satu solusi atau alternatif dalam pembelajaran matematika yang inovatif. Sejalan dengan Kodirun, Busnawir, \& Viktor (2016: 93) dalam penelitiannya bahwa dengan menerapkan model discovery learning berhasil meningkatkan kemampuan komunikasi matematis siswa. Didukung juga dari penelitian Ramdhani, Usodo, \& Subanti (2017: 1) yang menyimpulkan model discovery learning dapat meningkatkan hasil belajar siswa. Kemudian diperkuat dengan pendapat Suyitno, Nurul, \& Budhiati (2019: 1) mengemukakan model discovery learning cocok diterapkan untuk meningkatkan pemahaman konsep materi geometri berdasar hasil analisis kemampuan pemahaman konsep matematis siswa per indikator yang mengalami peningkatan dengan sangat baik. Selain itu, Suprihatiningrum (2017) menyatakan bahwa model pembelajaran discovery learning memiliki beberapa kelebihan yaitu, melalui penerapan model pembelajaran penemuan (discovery learning) maka materi yang dipelajari lebih lama membekas, karena siswa dilibatkan dalam proses menemukannya, membantu siswa untuk lebih mandiri, mengarahkan diri sendiri, bertanggung jawab atas pembelajarannya sendiri, melalui latihan menyelesaikan masalah, seorang akan belajar bagaimana belajar (learning how to learn), dan yang terpenting informasi yang dibangun sendiri melalui penemuan terbimbing akan lebih mudah mendapatkan kembali informasi yang telah tersimpan dalam memori otak.

Adapun penelitian yang dilakukan oleh Mawaddah \& Maryanti (2016: 76) juga menjelaskan hasil penelitiannya tentang kemampuan pemahaman konsep matematis siswa SMP dalam pembelajaran menggunakan discovery learning yang menyatakan bahwa kemampuan pemahaman konsep matematis siswa dalam pembelajaran matematika dengan discovery learning secara keseluruhan berada pada kategori baik dan respon siswa cenderung setuju terhadap pembelajaran matematika dengan model tersebut berdasarkan pada hasil analisis data mean (rata-rata) dan persentase. 


\section{SIMPULAN}

Peningkatan kemampuan pemahaman konsep matematis siswa di SMP Negeri 1 OKU berbeda pada setiap indikatornya. Dari ketujuh indikator kemampuan pemahaman konsep yang paling tinggi peningkatannya pada indikator kedua, yakni siswa mampu menetapkan objek-objek menurut sifat-sifat tertentu mengalami peningkatan dengan indeks gain 0,97 dengan interpretasi tinggi. Dengan demikian, dapat dikatakan bahwa peningkatan kemampuan pemahaman konsep matematis siswa di SMP Negeri 1 OKU dikategorikan tinggi setelah diterapkannya model pembelajaran penemuan (discovery learning). Oleh karena itu, model discovery learning dapat menjadi salah satu alternatif dalam pembelajaran matematika yang inovatif untuk meningkatkan kemampuan pemahaman konsep matematis siswa.

\section{DAFTAR PUSTAKA}

Aisyah, M. N., Sumintono, B., \& Ismail, Z. (2014). Pemahaman Siswa pada Pokok Bahasan Peluang: Studi Kasus di Suatu Sekolah Menengah di Johor Bahru, Malaysia. Jurnal Pengajaran MIPA, 19(1), 19-28. Retrieved from http://eprints.um.edu.my/9996/1/Pemahaman_siswa_pada_pokok_bahasan_ peluang_Maizatul-Bambang-Zaleha.PDF.pdf

Andinasari, Zulkardi, Somakim, \& Wasiran, Y. (2018). Learning Design of Reciprocal Proportionality Using Airplanes Contex. Journal of Physics: Conf. Series 1166 (2019) 012018. https:/ / doi.org/10.1088/1742-6596/1166/1/012018

Arikunto, S. (2014). Proses Penelitian. Jakarta: PT. Rineka Cipta.

Hamzah, A. (2014). Perencanaan dan Strategi Pembelajaran Matematika. Jakarta: PT. Raja Grafindo Persada.

Kodirun, Busnawir, \& Viktor, E. B. (2016). Penerapan Model Pembelajaran Discovery Learning Berbasis Lesson Study dalam Upaya Peningkatan Kemampuan Komunikasi Matematik Siswa Kelas X MIPA-3 SMA Negeri 5 Kendari. Jurnal Pendidikan Matematika, 7(2). Retrieved from http://ojs.uho.ac.id/index.php/JP $\mathrm{M} /$ article/view/3085/pdf

Kurniadi, G., \& Purwaningrum, J. P. (2018). Discovery Learning Berbantuan Asesmen Hands On Activities. ANARGYA: Jurnal Ilmiah Pendidikan Matematika Vol.1, 1(1). Retrieved from https://jurnal.umk.ac.id/index.php/anargya/article/view/24 $63 / 1376$

Lestari, K. E. (2015). Penelitian Pendidikan Matematika. Bandung: PT. Refika Aditama.

Lusiana. (2018). Integrasi Kearifan Lokal dalam Pembelajaran Matematika dengan Pendekatan Contekstual Learning. Wahana Didaktika, 16(3), 366-375.

Mawaddah, S., \& Maryanti, R. (2016). Kemampuan Pemahaman Konsep Matematis Siswa SMP dalam Pembelajaran Menggunakan Model Penemuan Terbimbing (Discovery Learning). EDU-MAT Jurnal Pendidikan Matematika, 4(1), 76-85. Retrieved from https://ppjp.ulm.ac.id/journal/index.php/edumat/article/vie $\mathrm{w} / 2292 / 2010$

Ramdhani, M. R., Usodo, B., \& Subanti, S. (2017). Discovery Learning with Scientific 
Approach on Geometry Discovery Learning with Scientific Approach on Geometry. Journal of Physics: Conf. Series $895 \quad$ (2017) 012033. https://doi.org/10.1088/1742-6596/895/1/012033

Suprihatiningrum, J. (2013). Metode Penelitian Kuantitatif (Dilengkapi dengan Perhitungan Manual dan Aplikasi SPSS Versi 17). Jakarta: Kencana Prenada Media Group.

Suprihatiningrum, J. (2017). Strategi Pembelajaran. Yogyakarta: A-Ruzz Media.

Suyitno, H., Nurul, E., \& Budhiati, R. (2019). The Development of Geometry Concepts Understanding Based on NCTM Reference in Learning Using Discovery Learning Model. Unnes Journal of Mathematics Education, 8(1), 42-48. https://doi.org/10.15294/ujme.v8i1.28683

Zaini, K. (2018). Penerapan Model Pembelajaran Student Facilitator and Explaining (SFAE ) untuk Meningkatkan Kemampuan Pemahaman Konsep Aljabar Linier Mahasiswa Universitas. Jurnal Equation: Teori dan Penelitian Pendidikan Matematika, 1(1), 111-120. Retrieved from https://ejournal.iainbengkulu.ac.id/ index.php/equation/article/view/1354/1144 